YEARBOOK

of ANTITRUST

and REGULATORY

STUDIES

www.yars.wz.uw.edu.pl
Peer-reviewed scientific periodical, focusing on legal and economic issues of antitrust and regulation.

Creative Commons Attribution-No Derivative Works 3.0 Poland License.

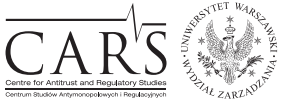

Centre for Antitrust and Regulatory Studies, University of Warsaw, Faculty of Management www.cars.wZ.uw.edu.pl

\title{
Competition Law Enforcement in Italy after the ECN+ Directive: the Difficult Balance between Effectiveness and Over-enforcement
}

\author{
by \\ Giacomo Dalla Valentina*
}

\section{CONTENTS}

I. Introduction

II. A dual transposition of the ECN+ Directive? Possible risks for the Italian legal system

III. The impact of the ECN+ Directive on the enforcement by the Italian Competition Authority
A. Fining powers
B. Behavioral and structural remedies
C. Investigative powers
D. Leniency applications

IV. The issue of independence

V. Conclusions

\section{Abstract}

Almost fifteen years after its adoption, the system of decentralized enforcement laid down in Regulation 1/2003 has shaped competition law in a way that could hardly be predicted, in terms of both magnitude and quality of the activities of National Competition Authorities. More recently, the so-called 'ECN+ Directive' was adopted to address the shortcoming of such system, namely a perceived lack of independence and accountability of several NCAs and a certain degree of divergence within the European Competition Network. In this scenario, the Italian Competition Authority has frequently been depicted as a well-equipped,

* Ph.D. candidate in EU Competition Law at University of Milan - Faculty of Law; e-mail: giacomo.dallavalentina@unimi.it. Article received: 16 July 2019; accepted: 5 September 2019. 
independent and effective enforcer and - with a few notable exceptions - the international debate concerning such reform has mostly overlooked its possible impact within the Italian legal system. This paper aims to assess whether, and to what an extent, the ECN + Directive should affect the enforcement of competition law in Italy and, in particular, those fundamental guarantees of independence and effectiveness that form the core of the rule of law in the field of EU competition law.

\section{Résumé}

Presque quinze ans après son adoption, le système d'application décentralisée prévu par le règlement $n^{\circ} 1 / 2003$ a influencé le droit de la concurrence d'une manière difficilement prévisible, tant en termes d'ampleur que de qualité des activités des autorités nationales de concurrence. Plus récemment, la directive dite «ECN+» a été adoptée pour remédier aux lacunes de ce système, à savoir le défaut d'indépendance et de responsabilité de plusieurs autorités nationales de concurrence et un certain degré de divergence au sein du réseau européen de la concurrence. Dans ce scénario, l'autorité italienne de la concurrence a souvent été présentée comme une autorité bien équipée, indépendante et efficace, et - à moins de quelques exceptions - le débat international concernant cette réforme a pour la plupart négligé son impact possible dans le système juridique italien. Le présent article vise à établir si, et dans quelle mesure, la directive ECN+ doit affecter l'application du droit de la concurrence en Italie et, en particulier, les garanties fondamentales d'indépendance et d'efficacité qui constituent le fondement de l'État de droit dans le domaine du droit communautaire de la concurrence.

Key words: Competition Law, Public Antitrust Enforcement, Italian Competition Authority, ECN+ Directive

JEL: K21

\section{Introduction}

'Fate che le leggi sian chiare, semplici, e che tutta la forza della nazione sia condensata a difenderle'.

With these words, written in 1765, the Italian philosopher and scholar Cesare Beccaria, while advocating the ending of torture and death penalty, stressed the importance of clear and straightforward laws, accompanied by a united and coherent effort from public institutions.

1 'Let the laws be clear and simple; let the entire force of the nation be united in their defence' (Beccaria, 1764). 
In the words of the European Commission (hereinafter: Commission), 'better results through better application'2. That is, in essence, the trait d'union behind the highly anticipated, if not hyped, adoption of Directive (EU) 2019/1 (hereinafter: Directive), aimed at empowering the national competition authorities (hereinafter: NCAs) of the Member States to be better enforcers, strengthening competition across the EU and, ultimately, giving consumers a better choice of goods and services at lower prices and of better quality ${ }^{3}$.

Indeed, the main areas of intervention to unleash the 'untapped potential' of the NCAs were already identified in the Commission's 2014 Communication marking the $10^{\text {th }}$ anniversary of Regulation $1 / 2003^{4}$. They have been subsequently subject to wide scrutiny, which became much more intensive when, on March 2007, the Commission presented a proposal to entrust the NCAs with more effective powers (hereinafter: Proposal) ${ }^{5}$.

The background is well-known: Regulation $1 / 2003^{6}$ put in place a system of parallel competences, in which the NCAs of the Member States were entrusted with the task of applying EU competition rules, namely Articles 101 and 102 of the Treaty on the Functioning of the European Union (TFEU) alongside the Commission. Since then, the Commission and the NCAs have enforced the EU competition rules in close cooperation within the European Competition Network (hereinafter: ECN), created in 2004 expressly for this purpose ${ }^{7}$.

2 Communication from the Commission, EU law: Better result through better application, C/2016/8600, (OJ C 18, 19.01.2017, p. 10).

3 Directive (EU) 2019/1 of the European Parliament and of the Council of 11 December 2018 to empower the competition authorities of the Member States to be more effective enforcers and to ensure the proper functioning of the internal market, PE/42/2018/REV/1 (OJ L 11, 14.1.2019, p. 3-33).

${ }^{4}$ Communication from the Commission to the European Parliament and the Council Ten Years of Antitrust Enforcement under Regulation 1/2003: Achievements and Future Perspectives, COM/2014/0453 final.

5 Proposal for a Directive of the European Parliament and of the Council to empower the competition authorities of the Member States to be more effective enforcers and to ensure the proper functioning of the internal market. COM/2017/0142 final - 2017/063 (COD). For some earlier comments on the Proposal see, e.g., Sinclair, 2017; Wils, 2017, pp. 60-80; Ghezzi, Marchetti, 2017, pp. 1015-1075.

${ }^{6}$ Council Regulation (EC) No 1/2003 of 16.12 .2002 on the implementation of the rules on competition laid down in Articles 81 and 82 of the Treaty (OJ L 1, 04.01.2003, p. 1-25).

7 See the Commission Notice on cooperation within the Network of Competition Authorities (OJ C 101, 27/04/2004 p. 43-53), the Joint Statement of the Council and the Commission on the functioning of the network (document No 15435/02 ADD 1), as well as Recital no. 15 of Regulation 1/2003, which provided that 'the Commission and the competition authorities of the Member States should form together a network of public authorities applying the Community competition rules in close cooperation. For that purpose it is necessary to set up arrangements 
While the scale of the enforcement activity increased at an impressive rate ${ }^{8}$, and the NCAs quickly became a fundamental pillar of the application of EU competition rules, few institutional and procedural issues were brought to the attention of the ECN. In particular, the main worries regarded the existence of divergences in national procedures, the institutional position of the NCAs and the adequacy of their decision-making and investigation powers - all topics that were left open by Regulation 1/2003, which left a large degree of flexibility for the design of competition regimes within the Member States.

Since the first years of its existence, the ECN concentrated its activity in making the NCAs fit to fully cooperate and 'enhance their ability to jointly address competition problems and ensure convergence' 9 . Convergence and harmonization are, indeed, at the core of the thorough activity of the ECN, which culminated in the adoption of several recommendations and the publication, between 2012 and 2013, of two reports related to decision-making and investigative powers of the NCAs. The ECN reports showed that, notwithstanding the lack of specific EU law provisions, there had been a significant degree of voluntary convergence of Member States' laws regulating public enforcement of EU competition law, with homogenous basic elements of decision-making and investigative powers, as well as crucial procedural tools, present in all, or in a large number of, jurisdictions. Nonetheless, according to the ECN, the efforts that brought to this result did not led to uniformity and several divergences relating to fundamental topics were still in place. Both reports ended by pointing out that it was time for a further and informed debate concerning 'to which extent a further harmonization [was] desirable or needed, taking account of the cost involved'.

These recommendations and reports were crucial in delivering a wide analysis of the state of the art of public enforcement of EU competition law and are, in fact, at the heart of the Proposal, which can be seen as the output of a process of horizontal cooperation (Ghezzi, 2017).

The aim of this paper is to assess whether, and to what an extent, the entry into force of the Directive and its future implementation in the Italian legal system - which is often said to provide one of the most effective and 'lenient'

for information and consultation. Further modalities for the cooperation within the network will be laid down and revised by the Commission, in close cooperation with the Member States'.

8 According to the Explanatory Memorandum attached to the Proposal, since 2004 the Commission and the NCAs took over 1000 enforcement decisions, with the NCAs being responsible for $85 \%$ of them.

${ }^{9}$ European Competition Network, Resolution of the Meeting of Heads of the European competition authorities of 16.11.2010, Competition authorities in the European Union - the continued need for effective institutions, p. 2. 
legal frameworks for competition law enforcement ${ }^{10}$ - will improve the public enforcement of EU (and, possibly, domestic) competition law in Italy.

\section{A dual transposition of the ECN+ Directive? Possible risks for the Italian legal system}

In line with the experience of Directive 2014/104/EU, governing the actions for damages for infringements of the competition law provisions (hereinafter: Damages Directive) $)^{11}$, Articles 103 and 114 TFEU represents the legal basis of the Directive.

The provision of such joint legal basis does not raise a merely theoretical point. In fact, the reference to Article $103 \mathrm{TFEU}^{12}$ and to the "establishment and functioning of the internal market' included in Article 114 TFEU implies that the scope of application of the Directive will be limited to 'the application of Articles 101 and 102 TFEU and the parallel application of national competition law to the same case', hence excluding, with few exceptions ${ }^{13}$, all anti-competitive behaviors that do not trigger intra-community trade and that the NCA would decide exclusively under national competition law ${ }^{14}$.

The possibility of a dual implementation of the Directive raises some concerns, with specific regard to the possibility that this limited scope might

10 See, e.g., Assonime, European Commission consultation "Empowering the National Competition Authorities to be more effective enforcers" - Some comments, 4/2016: 'in Italy, the enforcement toolbox at disposal of the AGCM seems quite comprehensive and well-functioning' (p. 4).

11 Directive 2014/104/EU of the European Parliament and of the Council of 26 November 2014 on certain rules governing actions for damages under national law for infringements of the competition law provisions of the Member States and of the European Union (OJ L 349, 05.12.2014, pp. 1-19).

12 Article 103 allows the Council, following a proposal of the Commission and having received a non-binding opinion of the EU Parliament, to adopt 'appropriate regulations or directives to give effect to the principles set out in Articles 101 and 102'.

13 See Articles 29(2) and 4 of the Directive, concerning, respectively, the suspension/ interruption of the limitation period for the imposition of fines as long as the NCA's decision is subject of proceedings pending before a review court, and the independence requirements of NCAs.

14 Pursuant to Article 2 of the Directive, 'national competition law' means 'provisions of national law that predominantly pursue the same objective as Articles 101 and 102 TFEU and that are applied to the same case and in parallel to Union competition law pursuant to Article 3(1) of Regulation (EC) No 1/2003, as well as provisions of national law that predominantly pursue the same objective as Articles 101 and 102 TFEU and that are applied on a stand-alone basis as regards Article 31(3) and (4) of this Directive, excluding provisions of national law which impose criminal penalties on natural persons'. 
favor the implementation of a differentiated set of procedural and institutional rules from Member States that are not willing, or do not deem it necessary, to grant more powers to their NCAs. In this scenario, the provisions of the Directive would apply only to NCAs' decisions and proceedings under Articles 101 and 102 TFEU, while all proceedings initiated under national competition law would be regulated by the pre-existing (and, most certainly, less incisive) set of rules. This discrepancy would entail a number of complexities (both for the NCAs and the undertakings subject to investigations) and, in the end, the risk of jeopardizing the overall goals of the Directive (Botta, 2017) ${ }^{15}$.

As far as Italy is concerned, at the present time there is still no indication on whether the legislator will extend the provisions of the Directive to national competition law or maintain, alongside the rules of the Directive, the pre-existing legal framework, namely Law 10 October 1990, no. 287 (hereinafter: Italian Competition Act).

Despite the above, the risk of dual transposition and uneven application of the rules provided in the Directive appears remote for a number of reasons. Firstly, it might be useful to look at the recent experience of the implementation of the Damages Directive that, as anticipated, was adopted on the same legal basis. The Italian legislator implemented the Damages Directive with Decree 3/2017'6, which extended the substantial and procedural rules concerning private antitrust litigation also to national law as a single regime.

Furthermore, the Italian NCA (the AGCM) has traditionally applied EU competition law consistently and widely. According to the 2009 Commission's Staff Working Paper accompanying the Report on the functioning of Regulation 1/2003, from 2004 to 2009 'roughly one half of the enforcement decisions adopted by the Italian competition authority during the reporting period were based on Community law' ${ }^{17}$. This was partly due to a peculiarity of the Italian legal system that, until 2017, was characterized by the so-called 'single legal barrier', meaning that in cases where a breach of Articles 101 and/ or 102 TFEU was established, the Italian NCA did not apply in parallel national

15 According to Botta, this problem could have been avoided by adopting the Directive under a different legal basis than Articles 103 and 114 TFEU, namely under Art. 352(1) TFEU, which provides that 'if action by the Union should prove necessary, within the framework of the policies defined in the Treaties, to attain one of the objectives set out in the Treaties, and the Treaties have not provided the necessary powers, the Council, acting unanimously on a proposal from the Commission and after obtaining the consent of the European Parliament, shall adopt the appropriate measures'. The Author, however, acknowledges the difficulty to gain the political support of all Member States.

16 Legislative Decree 19.01.2017, no. 3 (OJ no.15 of 19.01.2017)

17 European Commission, Staff working paper accompanying the Communication from the Commission to the European Parliament and Council - Report on the functioning of Reg. 1/2003, $\operatorname{COM(2009)206~final,~p.~} 148$. 
law $^{18}$. This rule was later abrogated with Decree 3/2017, which amended the Italian Competition Act allowing for the parallel application of national and EU competition law provisions.

Notwithstanding the overcoming of the single legal barrier system, the Italian NCA's approach was always aimed at applying both substantial and procedural cases regulated by either EU or national law in a consistent manner. This, in addition to the other above-mentioned circumstances, and in the absence of any contrary evidence, leads to the conclusion that the implementation of the Directive will be carried out with a scope so as to include the enforcement of national competition law.

\section{The impact of the ECN+ Directive on the enforcement by the Italian Competition Authority}

\section{A. Fining powers}

The formal recognition of the principle of 'single economic unity'

Currently, the system of administrative fines that the Italian NCA may impose is modeled on the provisions of Regulation 1/2003.

In fact, the first paragraph of Article 15 of the Italian Competition Act reflects Article 23 of Regulation 1/2003 by providing that the Italian NCA may decide, depending on the gravity and the duration of the infringement, to 'impose a fine up to ten per cent of the turnover of each undertaking or entity during the prior financial year'. The second paragraph deals with the additional fine that the Italian NCA may impose in case of non-compliance with the fine imposed in accordance with the first paragraph. A third paragraph (no. 2-bis) was finally introduced in $2001^{19}$ and provides that the Italian NCA, 'in accordance with EU law, will use a general provision of its own to define the cases in which, based on assistance by companies under investigation in ascertaining infringements of competition rules, the fine may either not be levied or may be reduced in cases foreseen by EU law'.

Similarly, the 2014 Guidelines adopted by the Italian NCA on the application of the criteria for the quantifications of fines ${ }^{20}$ present strong analogies with

18 According to the ECN Report on Decision-Making Powers, this Italian system was the only one within the ECN that did not allow for the application of national competition rules in parallel with Articles 101 and 102 TFEU.

19 See Law of 05.03.2001, no. 57 (O.J. no. 66 of 20.03.2001).

${ }^{20}$ Italian NCA Resolution no. 25152 of 22.10 .2014 - Guidelines on the method of setting pecuniary administrative fines pursuant to Article 15, par. 1, of Law no. 287/90. 
the Commission's Guidelines on the method of setting fines imposed pursuant to Article 23(2)(a) of Regulation No 1/2003 (Cazzato, 2018).

Although, based on the above, the general features of the Italian NCA sanctioning system appear to be line with EU law, the Directive sets forth certain provisions that could have a substantial impact on the firepower of the Italian regulator.

I refer, in particular, to the principle introduced under Recital no. 46 of the Directive, which provides that the notion of 'undertaking' should be applied by the NCAs in accordance with the case law of the Court of Justice of the European Union (CJEU) and, specifically, in a sense that it 'designates an economic unit, even if it consists of several legal or natural persons'. This is formally laid down in Article 13(5) of the Directive, which prescribes that 'for the purpose of imposing fines on parent companies and legal and economic successors of undertakings, the notion of undertaking applies' - in the meaning of any entity engaged in an economic activity, regardless of its legal status and the way in which it is financed.

The long-standing legal concept of single economic unit ${ }^{21}$ mainly serves the purpose of expanding the scope of the competition authorities' enforcement powers vis-à-vis parent companies, as the latter can be found liable and, thus, be fined for the conduct of one of their subsidiaries, insofar as they form, indeed, a single economic unit.

The formalization of this principle through the Directive's implementing legislation will arguably have crucial consequences in the enforcement activities carried out by the Italian NCA, which - despite an established case law of the CJEU - has been shy in evaluating the liability of a company on the basis of the single economic unity.

Indeed, the notion of 'single economic unit' started to appear in the recent decisional practice of the Italian NCA, however without main practical implications for the quantification of the fines.

For example, in the 2017 Reinforcing Steel Bars case, the Italian NCA, while claiming on the one hand that 'the concept of undertaking covers, for the purposes of competition law enforcement, any entity which is engaged in an economic activity, regardless of its legal status and the way in which it is financed [and] such concept must be construed as it designates an economic

${ }^{21}$ See, for a first reference, the Judgment of the Court of 14.07.1972, case 48-69, Imperial Chemical Industries Ltd. $v$ Commission of the European Communities, ECLI:EU:C:1972:70, where the CJEU stated that 'where a subsidiary does not enjoy real autonomy in determining its course of action in the market, the prohibitions set out in Article 85(1) may be considered inapplicable in the relationship between it and the parent company with which it forms one economic unit' (para. 134) and, therefore, 'In view of the unity of the group thus formed, the actions of the subsidiaries may in certain circumstances be attributed to the parent company' (para. 135). 
unit, albeit from a legal point of view, the economic unit is made up of several natural or legal persons ${ }^{22}$, did not use the turnover of the entire group for the calculation of the fines for several companies.

Similarly, in the 2012 Road Barriers cartel23, as well as in a 2017 bid rigging case related to financed technical assistance services to the Public Administration in EU-financed programmes ${ }^{24}$, the Italian NCA used the single economic unit construct to hold the controlling entities liable, but at the same time it clarified that such companies were individually involved in the competition law infringements, thus depriving the use of the single economic unit concept of any practical implications (Ghezzi, 2017).

More recently, in deciding the 2018 Car financing cartel case ${ }^{25}$, the Italian NCA used the single economic unity principle in a fashion closer to the case-law of EU courts, as it assessed that the parties to the proceedings and their parent companies (either controlling the entire corporate capital of their subsidiaries or not) were part of single economic units and therefore took into account the group turnovers in order to determine the maximum legal thresholds of the fines. However, it is worth mentioning that the Italian NCA decided to waive the application of such principle vis-à-vis two of the parties 'because of the novelty of the approach adopted by the Authority to attribute the responsibility for the infringement also to parent companies that, albeit not owning all or almost all of the undertakings with them constitute a single economic entity for antitrust purposes'.

In conclusion, the full implementation of the Directive and, by this, the formal recognition of the notion of 'undertaking' shaped by the CJEU will presumably resonate in the quantification of the fines by the Italian NCA, especially considering that the latter has recently shown some signs of convergence towards the approach of the CJEU and the Commission. The amount of those fines, also in order to ensure legal certainty for companies operating across the EU, will have to reflect the overall strength of the corporate group and not only that of the subsidiary, making it more meaningful and deterrent ${ }^{26}$.

22 Italian NCA, case no. I742 - Tondini per cemento armato, 19.07.2017, par. 331.

23 Italian NCA, case no. I723 - Intesa nel mercato delle barriere stradali, 28.09.2012.

${ }^{24}$ Italian NCA, case no. I796 - Servizi di supporto e assistenza tecnica alla PA nei programmi cofinanziati dall'UE, 18.10.2017.

25 Italian NCA, case no. I811 - Finanziamenti auto, 20.12.2018.

26 See European Commission Staff Working Document, Impact Assessment Accompanying the Document Proposal for a Directive of the European Parliament and of The Council to empower the competition authorities of the Member States to be more effective enforcers and to ensure the proper functioning of the internal market, 22.03.2017 SWD(2017) 114 final, $1 / 2$. 
Finally, it is worth mentioning that the Directive also intervenes on the maximum amount of the fines imposed by the NCAs. While Regulation 1/2003 as well as the majority of the NCAs - provided that the fines shall not exceed $10 \%$ of the infringer's total turnover, the Directive now foresees that 'the maximum amount of the fine that national competition authorities may impose on each undertaking or association of undertakings participating in an infringement of Article 101 or 102 TFEU is not less than 10\%', theoretically allowing Member States to increase the ceiling for competition law fines in their systems.

\section{Heavier sanctions against trade organizations}

Another relevant development brought by the Directive in relation to the Italian NCA's sanctioning powers concerns trade organizations, which often play a pivotal role in the implementation of collusive conducts ${ }^{27}$.

The clear aim underlying the Directive (according to Recital no. 48, 'NCAs should [...] be able to fine such associations effectively') is achieved by looking at two areas that were traditionally problematic for the NCAs, including the Italian authority.

On the one hand, the Directive addresses the methods for calculating the turnover of trade organizations for the purposes of the quantification of the fine. The notion of 'turnover', in particular, has been construed in a conservative way by the Italian NCA with regard to association of undertakings, namely as the sum of the annual quotas paid by the members of the association.

Therefore, it is fair to say that - especially in the presence of wide-reaching cartels - the fines levied against trade associations were hardly sufficient to have any deterrence effects ${ }^{28}$. Now, the Directive provides that, in order to determine the amount of the fine in proceedings brought against associations of undertakings, where the infringement relates to the activities of its members, the NCAs should consider the 'sum of the sales of goods and services to which the infringement directly or indirectly relates by the undertakings that are members of the association' 29 .

27 Between 2010 and 2017, the Italian NCA ascertained the direct involvement of trade associations in roughly $60 \%$ of its infringement decisions (Ghezzi, Marchetti, 2017).

28 This was also held by the CJEU back in the Judgment of the Court of 16.11.2000, case C-298/98 P, Metsä-Serla Sales Oy v Commission, European Court reports 2000, p. I-10157: "when a fine is imposed on an association of undertakings, whose own turnover most often does not reflect its size or power on the market, it is only when the turnover of the member undertakings is taken into account that a fine with deterrent effect can be determined'.

29 See Recital no. 48 of the Directive, which also specifies that 'when a fine is imposed not only on the association but also on its members, the turnover of the members on which a fine is imposed should not be taken into account when calculating the fine of the association'. 
Article 14(3) of the Directive provides that, where a fine is imposed on an association of undertakings and the association is not solvent, the association is obliged to call for contributions from its members to cover the amount of the fine.

On the other hand, if these contributions have not been made in full to the association of undertakings within the time limit fixed by the NCA, the latter may require the payment of the fine 'directly by any of the undertakings whose representatives were members of the decision-making bodies of that association' and, after this request, also 'by any of the members of the association which were active on the market on which the infringement occurred'. To avoid aberrant consequences, the Directive still allows the members of a trade organization to avoid such payment obligation by proving that they did not implement the infringing decision of the association and either were not aware of its existence or have actively distanced themselves from it before the investigation started.

In conclusion, the Directive lays the ground for an empowerment of the Italian NCA's firepower against associations of undertakings. The guaranteed increase of the sanctions to trade organizations, along with the possibility to retrieve the fines from their members, will certainly add a new tool to the Italian NCA's arsenal to challenge the frequently active role of associations of undertakings in the implementation of cartels.

Such tools should, however, be used parsimoniously: the Italian NCA's habit of using legitimate activities of trade associations as control tools and evidence of the existence of cartels has had the effect of paralyzing licit activities of the associations (Siragusa, 2017), which will probably be even more difficult in the wake of the implementation of the Directive.

\section{B. Behavioral and structural remedies}

Article 10 of the Directive replicates the content of Article 7 of Regulation 1/2003 in prescribing that, where NCAs find an infringement of Article 101 or 102 TFEU, they may 'impose any behavioural or structural remedies which are proportionate to the infringement committed and necessary to bring the infringement effectively to an end'. The Directive further specifies that, in choosing between two equally effective remedies, NCAs shall choose the least burdensome remedy for the undertaking, in line with the principle of proportionality.

The divergence within the EU concerning the power to impose structural remedies when applying EU competition rules, red-flagged by the ECN in 
an ad hoc 2013 Recommendation ${ }^{30}$, also affects the Italian legal system, where structural and behavioral remedies were never formally recognized in the Italian Competition Act nor in any procedural rule adopted by the Italian $\mathrm{NCA}^{31}$.

It is worth noting that, despite lacking a clear legal basis, the Italian NCA has tried in the past to put in place such remedies, which did not find wide consensus and were eventually annulled on appeal by administrative courts due to the lack of a legal basis. For example, in the Airport supplies case ${ }^{32}$, the Council of State held that 'the sanctioning measures for anti-competitive conduct $[\ldots]$ provided for in Article 15 may be translated only into warnings for the elimination of infringements, within a certain period, and into the imposition of pecuniary fines, but not into the imposition of structural behavioral measures affecting private autonomy and economic initiative'. On another occasion, however, the same Court upheld the Italian NCA's remedies considering that 'in the presence of historical events already put in place and of illicit behaviors which have their effects still in act, the ICA can adopt remedies [...] aimed at eliminating the effects of the infringements in the immediate future', provided that they respect the principles of suitability, necessity (that is, the absence of other suitable remedies) and adequacy'33.

These few national cases involving structural measures show that the lack of a clear legal basis has de facto prevented the Italian enforcer from benefitting from a tool, which has proved to be particularly effective especially in those cases where, due to various factors, the mere imposition of fines is not sufficient to tackle the anticompetitive conducts. An accurate implementation of Article 10 of the Directive will arguably encourage the Italian NCA to test structural and behavioral remedies with more confidence and will pave the way for a more open approach of administrative courts in deciding upon the legitimacy of these remedies.

30 See European Competition Network, Recommendation on the Power to Impose Structural Remedies, 2013, where it was highlighted that, albeit some national legislative frameworks are aligned with Article 7(1) of Regulation 1/2003, others differ, as some Member States' laws 'provide for an explicit legal basis which enables the Authorities to impose structural remedies', other Member States 'recognise such powers on a general legal basis which covers all types of remedies without being specific' and, finally, some NCAs 'are not equipped with this power at all'.

31 Indeed, with Law of 06.08.2006, no. 248, the Italian legislator put in place a series of amendments to the Italian Competition Act, in order to align its provisions with the standards and tools laid down in Regulation 1/2003. This intervention, however, did not acknowledge the provision of Article 7 of Regulation 1/2003 concerning structural and behavioral measures.

32 Judgement of the Italian Council of State of 08.02.2008, cases no. 421 and 423, Rifornimenti aeroportuali.

33 Council of State, 08.04.2014, no. 1673, Coop Estense. 


\section{Investigative powers}

The Directive is not only about decision-making and fining powers. As anticipated above, the ECN recommendations and the reports from the Commission shed light on a patchwork of different rules concerning, inter alia, the investigation powers of the NCAs.

In this regard, it is often said that the Italian NCA is well-equipped when it comes to its powers of investigation ${ }^{34}$. While this assumption is correct, especially when comparing the Italian authority's toolbox with other NCAs, the implementation of the Directive will arguably enhance further the effectiveness of the Italian NCA's powers in the investigation phase.

The main novelty for the Italian legal framework is included in Article 7 of the Directive, which provides that the power for the NCAs to inspect premises for the enforcement of Articles 101 and 102 TFEU should extends to non-business premises, such as 'the homes of directors, managers, and other members of staff of undertakings or associations of undertakings'.

The Italian NCA was one of the few authorities part of the ECN that was not granted specific powers to gather information located on these premises when investigating infringements of competition law. Therefore, Article 14 of the Italian Competition Act, which currently regulates the inspection powers of the Italian NCA, will have to be amended to include such new and rather pervasive power.

In any case, the Directive specifies that inspections in non-business premises shall not be carried out without the prior authorization of a judge, who has to ascertain whether there is 'a reasonable suspicion' that books or other records related to the business and to the subject matter of the inspection, which may be relevant to prove an infringement of Article 101 or Article 102 TFEU, are being kept in non-business premises.

The emphasis of the Directive on the effectiveness of the NCAs' investigative powers is also reflected in other provisions, which will likely determine the amendments of the Italian Competition Act.

Firstly, Recital no. 30 addresses the need for NCAs to have at their disposal powers that are adequate to meet the enforcement challenges of the digital environment and, in particular, to obtain all useful information related to the investigation, including data obtained forensically, 'irrespective of the medium on which the information is stored, such as on laptops, mobile phones, other mobile devices or cloud storage'. While the Italian NCA is already used to acquiring digital evidence, this power was based on the more general power to carry out inspections. Hence, the transposition of the Directive will bring

${ }^{34}$ See, inter alia, Assonime, European Commission consultation, cit., p. 4. 
a more detailed and appropriate legal basis for the Italian NCA's inspection activities.

Furthermore, the domestic legislation is going to be impacted by the provision - to be balanced with the constitutional right of defense and the privilege against self-incrimination - that where an undertaking or association of undertakings opposes an inspection, the Italian NCA will be able to 'obtain the necessary assistance of the police or of an equivalent enforcement authority so as to enable them to conduct the inspection' ${ }^{35}$.

At the present time, it is rather difficult to assess how, and to what an extent, the Italian legislator will transpose such provisions, also considering the need for the implementing legislation to comply with domestic rules concerning investigations and the right of defense. Surely, the main novelty will be the power for the Italian NCA to inspect non-business premises, a possibility that is not foreseen by the current legal framework. Moreover, with the formalization of a legal basis for inspections in the digital environment, the Italian NCA will have the chance to achieve the objective recently laid down in the Big Data guidelines and recommendations of policies, where it expressed the need, in order to allow a full understanding of the new phenomena taking place in the digital economy, to strengthen its own powers as to 'acquire information outside the investigation procedures (investigations, pre-instruction activities), including the possibility of imposing administrative sanctions in the event of refusal or delay in providing the information requested or in the presence of misleading or omissive information'36.

In conclusion, it is very much likely that the Italian NCA will find itself with a wider and undoubtedly more effective set of tools to lead the investigation phase.

\section{Leniency applications}

The Commission notably deems leniency programmes crucial in the enforcement of competition law, as they are a key tool whose potential in the discovery of highly secretive cartels, and their mere existence, can destabilize existing cartels.

The impact assessment accompanying the Proposal showed that there are, yet, several divergences and weaknesses in both the national leniency

35 See Article 6(2) of the Directive.

36 Italian NCA, AGCom and Italian Data Protection Authority, IC53 - Big data: the guidelines and recommendations of policies shared by the three Authorities, 10.07.2019, p. 10 . 
procedures and the cooperation among the NCAs and the Commission, which the Directive tries to address by providing a detailed set of rules.

In particular, the most relevant provision of the Directive is the one concerning summary applications. According to Article 22, where the Commission receives a full leniency application and the NCAs receive summary applications, the Commission will be the 'main interlocutor of the applicant, in the period before clarity has been gained as to whether the Commission intends to pursue the case in whole or in part'. During this period, the Commission will inform the NCAs about the state of play only at their request.

Also, NCAs will be prevented from requiring clarifications from the applicants in addition to the essential information of the summary application pursuant to Article 22(2) of the Directive ${ }^{37}$. Save for 'exceptional circumstances', NCAs will be able to require those clarifications in the event the Commission has informed them that 'it does not intend to pursue the case in whole or in part'.

The system envisaged by the Directive poses several problems and, in fact, has already been criticized by both those who believe it might endanger the principle of autonomy of the NCAs laid down by Regulation 1/2003 and stressed by the CJEU in DHL Express ${ }^{38}$ (Ghezzi, 2017), and those who disapproved of the Commission's failure to establish a leniency one-stop shop system (Wagner-von Papp, 2019).

In spite of the academic discussions on this extremely sensitive topic, it is without any doubt that the new rules on the coordination between leniency applications will have a profound impact on the Italian experience, which is currently regulated by Article 15(2-bis) of the Italian Competition $\mathrm{Act}^{39}$ and by the Italian NCA's Leniency Guidelines ${ }^{40}$.

37 Namely, the name and address of the applicant, the names of other parties to the alleged secret cartel, the affected products and territories, the duration and the nature of the alleged secret cartel conduct, the Member State(s) where the evidence of the alleged secret cartel is likely to be located and information on any past or possible future leniency applications made to any other competition authorities or competition authorities of third countries in relation to the alleged secret cartel.

38 Judgement of the Court of 20.01.2016, case C-428/14, DHL Express (Italy) Srl and DHL Global Forwarding (Italy) SpA v Autorità Garante della Concorrenza e del mercato, ECLI:EU:C:2016:27.

39 Article 15(2-bis) of the Italian Competition Act provides that 'the Authority, in conformity with EU law, will use a general provision of its own to define the cases in which, based on assistance by companies under investigation in ascertaining infringements of competition rules, the fine may either not be levied or may be reduced in cases foreseen by EU law'.

40 Italian NCA, Communication on the non-imposition and reduction of fines in accordance with Article 15 of Law 10 October 1990, no. 287, as amended by Resolution no. 24219 of 31.01.2013 (Bulletin no. 11 of 25.03.2013) and Resolution no. 24506 of 31.07.2013 (Bulletin no. 35 of 09.09.2013). 
On the one hand, the expansion of the powers of the Commission (which will benefit from an exclusive, even if just temporary, jurisdiction) and the symmetrical stand-still obligation placed upon the NCAs might entail longer proceedings and a more burdensome gathering of evidence, especially in those cases where the Commission will take a long time to assess whether to pursue the case.

On the other hand, the Directive might have a positive effect in the interplay between the leniency applicant's immunity and the position of staff and managers of said applicant, which - as of now - are exposed in some cases to criminal liability for the same conducts. For this purpose, Article 23(2) of the Directive provides that, under certain conditions, current and former directors, managers and other members of staff of immunity applicants 'are protected from sanctions imposed in criminal proceedings, in relation to their involvement in the secret cartel covered by the application for immunity from fines, for violations of national laws that pursue predominantly the same objectives to those pursued by Article 101 TFEU'.

In Italy, this provision will involve the rules on bid rigging in the context of public procurement, which may also constitute a crime under Articles 353, 354-bis and 354 of the Italian Criminal Code ${ }^{41}$. The same goes for Article 501-bis of the Italian Criminal Code in relation to speculative conduct aimed at limiting the output or increasing the prices of raw material, food products or first need products. Hence, the Italian criminal law framework might be amended in the context of the implementation of the Directive.

\section{The issue of independence}

Finally, few words must be said on the efforts made by the Directive to ensure the independence of NCAs. The Commission, acknowledging that some national laws prevents the NCAs from having 'the necessary guarantees of independence, resources, and enforcement and fining powers to be able to enforce Union competition rules effectively', tried to solve this issue by: (i) ensuring that staffers and management of NCAs perform their duties and exercise their powers independently from political and other external influence; (ii) explicitly excluding instructions from any government or other public or private entity; (iii) ensuring that they refrain from any action which is incompatible with the performance of their duties and exercise of their powers; (iv) prohibiting the dismissal of their management for reasons related

41 Royal Decree of 19.10.1930, no. 1398. 
to decision-making in specific cases; $(v)$ ensuring that they have the power to set their priorities in individual cases including the power to reject complaints for priority reasons $\mathrm{A}^{42}$.

The Italian NCA - which is currently funded on the basis of a mandatory fee (equal to EUR 0,06 per thousand) charged to all companies whose turnover exceeds EUR 50 million - appears to be granted with adequate human and economic resources to perform its institutional duties ${ }^{43}$. Nonetheless, there are two provisions that will have a concrete impact, namely the reference to a cooling-off period and the matter of prioritization.

In particular, Recital no. 18 provides that, in order to prevent their assessment from being jeopardized, heads, staff and those who take decisions 'should refrain from any incompatible actions, whether gainful or not, both during their employment or term of office and for a reasonable period thereafter'. This is not currently foreseen by the Italian Competition Act, nor by other domestic laws. Indeed, the issue of revolving doors exists, and the Italian legislator has recently dealt with it in regard to other regulators by introducing a two-year cooling-off period ${ }^{44}$.

The implementation of the Directive will certainly constitute a valuable opportunity for the legislator to decide if, and how, to deal with this sensitive topic.

Article 4(5) introduces the possibility, for NCAs, to set negative priorities, that is, to reject complaints on the grounds that they do not consider such complaints to be an enforcement priority. It is worth noting that this type of tool is different from positive priorities, consisting of the power to initiate investigations and proceedings ex officio, without having received any formal notification or complaint (Wils, 2011).

The introduction of the possibility for the Italian NCA to prioritize on the grounds foreseen by Article 4(5) of the Directive is more a matter of

42 See Proposal, Chapter III, p. 15. The lack of independence of some NCAs has been discussed by scholars for a long time and has also been subject to judicial scrutiny in the Judgment of the Court of 31.05.2005, Case C-53/03, Synetairismos Farmakopoion Aitolias \& Akarnanias (Syfait) and Others $v$ GlaxoSmithKline plc and GlaxoSmithKline AEVE, ECLI:EU:C:2005:333, $\S 31$, where the CJEU found that the Greek system of public enforcement did 'not appear to constitute an effective safeguard against undue intervention or pressure from the executive on the members of the [NCA]', due to the existence of 'no particular safeguards in respect of their dismissal or the termination of their appointment'

${ }^{43}$ See, e.g., Assonime, European Commission consultation, cit., p. 4, where the importance of maintaining an impartial and effective competition law enforcement is however stressed even 'if the NCA is given additional labour-intensive institutional competences', such as consumer protection, legality ratings and so on.

44 In particular, a two-year period of cooling-off was introduced with Law 24.06.2014, no. 90 with regard to the Bank of Italy, CONSOB (the public authority responsible for regulating the Italian financial markets) and IVASS (the Italian Insurance regulator). 
effectiveness than independence (Bruzzone, 2017), as it would help the Italian NCA to focus its resources on the basis of a cost-benefit analysis and in light of the principles established by the case-law of the CJEU ${ }^{45}$.

\section{Conclusions}

In conclusion, the implementation of the Directive in the Italian legal system will entail several amendments to the current legal framework: even for the Italian NCA - which is granted with sufficient powers and resources and has proven to be one of the most compliant system within the ECN - the Directive brings several innovations, which will hopefully increase the quality and volume of competition law enforcement in Italy.

The choice to adopt a Directive, rather than a Regulation, has lead us to wait (and hope) for a prompt and precise action by the Italian legislator, which is asked to implement and adapt the provisions of the Directive to the peculiarities of the Italian system, avoiding a dual implementation for EU and domestic national law that would be of detriment to legal certainty and effectiveness.

One thing is now certain: the Directive will strengthen both investigative and decision-making powers of the Italian NCA, which will arguably find itself much better equipped for tackling anticompetitive conducts in the cooperation with other NCAs and the Commission.

Whilst these additional tools appear to be proportionate to ensure the effectiveness of the enforcement activity of the Italian NCA, they will have to be used and implemented with caution, in order to avoid the risk of over-deterrence and prejudice to fundamental rights.

\section{References}

C. Beccaria (1819). Of Crimes and Punishments, Ed. Philip H. Nicklin, Philadelphia.

M. Botta (2017). The draft Directive on the powers of national competition authorities: the glass half empty and half full, European Competition Law Review, 38(10).

G. Bruzzone (2017). Indipendenza e fissazione delle priorità: quale ruolo per il public enforcement?, contribution to the conference I poteri delle autorità antitrust nazionali

45 See, inter alia, Judgment of the Court of First Instance of 18.09.1992, Case T-24/90, Automec Srl v Commission of the European Communities, ECLI:EU:T:1992:97, § 77. For a more recent reference, see Judgment of the General Court of 11.01.2017, T-699/14 - Topps Europe v Commission, ECLI:EU:T:2017:2. 
e le garanzie: verso la direttiva ECN+ organized by AssonImE and the Italian Antitrust Association (AAI), Rome, 20 November.

C. E. Cazzato (2018). Le Linee Guida sulla quantificazione delle sanzioni antitrust. Introduzione al calcolo delle ammende imposte dall'Autorità Garante della Concorrenza e del Mercato, Giappichelli.

F. Ghezzi (2017). Lefficacia dei poteri di enforcement delle autorità antitrust nazionali nella proposta di Direttiva europea e le possibili conseguenze sul sistema sanzionatorio italiano, Rivista delle Società.

F. Ghezzi, B. Marchetti (2017). La proposta di direttiva in materia di Rete europea della concorrenza e la necessità di un giusto equilibrio tra efficienza e garanzie, Rivista italiana di diritto pubblico comunitario, 5 .

A. Sinclair (2017). Proposal for a Directive to Empower National Competition Authorities to be More Effective Enforcers (ECN+), Journal of European Competition Law \& Practice, vol. 8, no. 10.

M. Siragusa (2017). contribution to the conference I poteri delle autorità antitrust nazionali e le garanzie: verso la direttiva ECN+ organized by Assonime and the Italian Antitrust Association (AAI), Rome, 20 November.

S. Thomas, M. Dueñas (2018). The draft provisions on antitrust fines in the Commission's ECN+ Proposal, ZWeR - Zeitschrift für Wettbewerbsrecht, 1.

F. Wagner-von Papp (2019). Directive of the European Parliament and of the Council to empower the competition authorities of the Member States to be more effective enforcers and to ensure the proper functioning of the internal market ("ECN Plus Directive"), Competition Policy International, January.

W. P. J. Wils (2011). Discretion and Prioritisation in Public Antitrust Enforcement, in Particular EU Antitrust Enforcement, World Competition, Vol. 34, No. 3.

W. P. J. Wils (2017). The European Commission's "ECN+": proposal for a directive to empower the competition authorities of the Member States to be more effective enforcers, Concurrences, No. 4. 